\title{
Finishing lambs in hill country
}

G.W. Sheath, R.W. Webby, W.J. Pengelly and C.J. Boom

Whatawhata Research Centre, MAF, Hamilton

ABSTRACT A series of farmlet experiments investigated the effects of lambing dates, grazing methods and weaning/disposal dates on lamb production. Ewe and bull performance was also assessed. Laud contour did not significantly affect November-January lamb growth rates. Slight weight differences $(\simeq 1 \mathrm{~kg})$ in lambs and ewes occurred with changes in weaning date, but later disposal of lambs reduced both ewe and bull weights. Lamb growth rates were best when weaned lambs grazed in front of ewes and bulls in a quick rotation (25 days). Lambing in early August compared with early September, increased lamb weights but reduced lamb number, bull weight gains and ewe liveweights. At current product values earlier lambing reduced returns per ha. Recommendations are made for finishing lambs within mixed livestock systems in hill country.

Keywords lamb, grazing management, hill country, agricultural systems, lambing date

\section{INTRODUCTION}

Stock policy decisions are the basic mechanism for matching feed supply and demand, especially in hill country where feed conservation is difficult or impossible. Appropriate lambing and calving times and integration of stock classes are crucial to coping with seasonal variation in pasture growth. Between-year variation in summer-autumn pasture growth is best handled by altering weaning and disposal dates of finishing stock. Given this base line, grazing management can help transfer and ration pasture during deficit periods and minimise the impact of pasture surplus.

A greater emphasis on finishing animals in hill country makes it more difficult to match feed supply and demand all year round. Demands of growing animals exacerbate feed deficits and the surge in feed requirements during lactation declines as the proportion of dry stock increases. Recommendations of Sheath et al. (1984) on how best to manage hill pastures during late spring-early summer did not take into account finishing lambs. Further, the effect of lambing, weaning and disposal dates on finishing systems in hill country has not been assessed. Heavier lambs are being sought by earlier lambing and later disposal.

A series of farmlet experiments at Whatawhata Research Centre during 1983-89 investigated the effect of grazing methods, weaning/disposal dates and lambing dates on lamb production, and on ewe and bull performance.

\section{EXPERIMENTS}

\section{Weaning date - land contour experiment (1983/84, 1984/85)}

Farmlets (5.5-6.0 ha) were balanced for differences in aspect and land contour $(1: 2$ area ratio for easy to steep contoured land). Animals were mixed-age Romney ewes $(6.5 / \mathrm{ha}$ ) plus progeny (equivalent to $125 \%$ weaning and 50:50 wether:ewe lamb ratio); 15-month Angus steers in 1983/84 (4/farmlet) and 15-month Friesian bulls in 1984/85 (4/farmlet). Experimental design was a $2 \times 2$ factorial with 3 replicates.

Treatments in 1983184 were:

- Early weaning and disposal (EW): Lambs were weaned on 14 Nov, grazed in front of ewe and cattle mobs and disposed of on 15 Dec.

- Late weaning and disposal (LW): Lambs were grazed with ewes until weaning on $15 \mathrm{Dec}$, and then grazed in front of ewe and cattle mobs until disposal of on 12 Jan.

- Easy contour control (EC): Grazing was aimed at controlling pasture quality of all easy land and some steep land (1.4-1.5 t DM/ha residuals on easy land).

- Steep contour control (SC): Grazing was aimed at controlling pasture quality of all steep land and some easy land (1.3- $1.4 \mathrm{t} \mathrm{DM/ha}$ residuals on steep land).

Treatment changes for 1984185 involved weaning on 12 Nov and disposal on 7 Jan for EW farmlets; and weaning on $14 \mathrm{Dec}$ and disposal on 7 March for LW farmlets.

Animals were allocated to treatments in early Nov of both years. Average start weights were $47.5 \mathrm{~kg}$ ewes, $19.7 \mathrm{~kg}$ lambs, $316 \mathrm{~kg}$ steers in 1983/84; and $46.8 \mathrm{~kg}$ ewes, 18.7 lambs, $337 \mathrm{~kg}$ bulls in 1984/85. Pasture control treatments ceased in mid-Jan and subsequent management aimed at removing rank pasture before March; flushing ewes during March; and operating a 60 to 70-day winter rotation until lambing in late August.

\section{Grazing management experiment (1985186)}

Mixed-age Romney x Coopworth ewes (6.5/ha) plus progeny (100\% weaning equivalent) and 15-month 
Friesian bulls (5/farmlet) were used in farmlets previously described. At weaning (6 Nov) animals were allocated to treatments and weights were 19.7, 48.8 and $256 \mathrm{~kg}$ for lambs, ewes and bulls respectively. Four grazing systems (replicated 3 times) were compared between 14 Nov and 15 Jan. Treatments were:

- Continuous stock (CS): Weaned ewes and lambs were spread across all easy and steep paddocks. Bulls grazed all paddocks at least twice during the treatment period. Easy and steep land pasture mass was 2100 and $1700 \mathrm{~kg} \mathrm{DM} /$ ha respectively.

- Steep control (SC): Lambs grazed in front of ewes and bulls. Preference was given to controlling pasture on steep land. Rotation length was 27 days and pasture residuals were 1450 and $1200 \mathrm{~kg} \mathrm{DM} / \mathrm{ha}$ for easy and steep paddocks.

- Quick rotation $(\mathrm{QR})$ : Lambs grazed in front of ewes and bulls within a 25 day rotation. All paddocks were alternately grazed easy/steep, and pasture residuals were 1520 and $1360 \mathrm{~kg} \mathrm{DM} / \mathrm{ha}$ for easy and steep paddocks.

- Slow rotation $(\mathrm{SR})$ : As for $(\mathrm{QR})$ but with a 45-day grazing rotation. Easy and steep pasture residuals were 1450 and $1250 \mathrm{~kg} \mathrm{DM} / \mathrm{ha}$.

Post-treatment management allowed: lambs to graze "controlled" pasture; ewes and bulls to remove rank pasture before March; and ewes to be flushed over March and April. All lambs were disposed of on 5 March.

\section{Early lambing experiment (1987188, 1988/89)}

A $2 \times 2$ factorial experiment, replicated 3 times, compared pasture improvement and lambing date (also see Webby et al. 1990). Farmlets (as previously described) carried Romney x Coopworth ewes $(9.2 / \mathrm{ha})$ and Friesian bulls ( $\mathbf{5} /$ farmlet). Bulls were introduced in Nov as 3-month weaners and disposed at ages of 18-20 months.

Early lambing was stimulated by using a social facilitation "ram effect" plus CIDRs (Knight 1983). Rams joined the ewes during the second week of Feb in both years and remained for 3 complete cycles.

$60-70 \%$ of the ewes held to the first cycle and mean lambing date was the second week of August. Rams were placed with "late-lambing" ewes during the first week of April, resulting in a peak of lambing in the first 2 weeks of Sept.

Lambs were weaned on 17 Nov in both years with lambs exceeding $30 \mathrm{~kg}$ (1987) and $27 \mathrm{~kg}$ (1988) being sold. Six lambs per ha were retained for finishing, these being the heaviest of both sexes and balanced 50:50 between ewe and cryptorchid lambs. The remaining lambs were disposed of as "stores". Lambs exceeding $32 \mathrm{~kg}$ liveweight were draughted in mid Jan 1988, remaining lambs being disposed of on $10 \mathrm{Feb}$ 1988. For the $1988 / 89$ year all retained lambs were sold on 19 Jan 1989. Potential lamb values at weaning were calculated on prices current at the time of weaning, while "sale" values were those actually received.

Grazing management during this experiment sought to:

- Establish a winter rotation after 2 mating cycles were completed. Bulls grazed ahead of ewes.

- Provide separate lambing and bull grazing areas during August-October.

- Priority feed weaned lambs plus bulls ahead of fastrotating ewe mobs (25-30 days) during Nov-Jan.

- Give preference to finishing 18-20 month bulls from Jan till disposal.

\section{RESULTS AND DISCUSSION}

\section{Weaning date - land contour experiments (1983/84, 1984/85)}

Steep land should receive preference for controlling pasture density and quality during Nov-Jan (Sheath et al. 1984), but a possible disadvantage is reduced lamb growth rates. Lamb growth rates were slightly lower $(5-10 \mathrm{~g} / \mathrm{d})$ where lambs dominantly grazed steep land, but differences were not statistically significant (Table 1). Any small disadvantage can be associated with lower post- and pre-graze pasture masses for steep paddocks. Between grazings pasture mass increased by $600-650$ and $300-350 \mathrm{~kg} \mathrm{DM} / \mathrm{ha}$ for easy and steep paddocks respectively. Pasture growth rates on steep land were unusually low ( 24 and $18 \mathrm{~kg} \mathrm{DM} / \mathrm{ha} / \mathrm{d}$ for 1983/84 and 1984/85 respectively), and rotation lengths should have been increased from 25 to 35 days for steep control farmlets.

In both years, lamb growth rates from mid-Nov to mid-Dee were slightly less for lambs weaned in midNov (9-1 1 weeks) compared with lambs that remained unweaned until mid-Dee (Table 1). There was no significant interaction with land contour. When early wean lambs were disposed of they still remained $1 \mathrm{~kg}$ lighter. In contrast, ewes weaned 1 month earlier were

Table 1 Lamb growth rates in weaning date - land contour experiments (g/d).

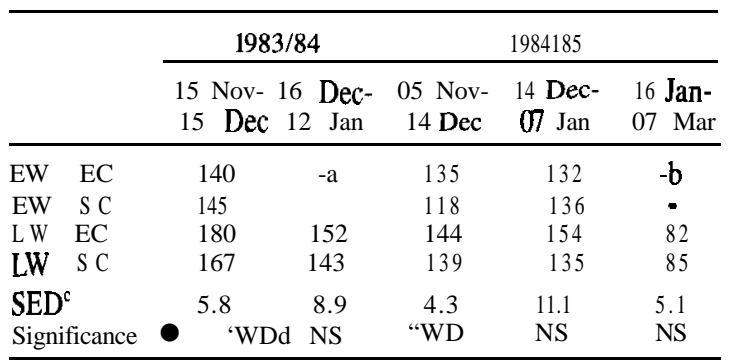

"EW lambs disposed on 15 December

bEW lambs disposed on 7 January

'Standard error of difference of main effects

${ }^{d} \mathbf{W D}$, significant for weaning date; LC, significant for land contour;

NS, non-significant 
$1 \mathrm{~kg}$ heavier at the early disposal date in both years (Dec 1983 and Jan 1984; Table 2).

Later disposal had a greater impact on the performance of other stock classes than did weaning date. In 1983/84 ewe weight gains from mid-Dee to mid-Jan continued to be greater with earlier lamb disposal, and steer weight gains were $0.2 \mathrm{~kg} / \mathrm{d}$ greater (Table 3). Similar results occurred in 1984/85 where lambs in late-weaned farmlets were retained until early March. While lamb liveweights increased by $4 \mathrm{~kg}$ between mid Jan and early March, ewe mating weights were $3 \mathrm{~kg}$ lighter and bulls were $10 \mathrm{~kg}$ lighter in body weight where disposal of lambs was delayed. Further, increased grazing pressure resulting from higher stock numbers in late wean/disposal farmlets, increased ewe exposure to facial eczema (Sheath et al. 1987). Late disposal increased cull and dry ewe numbers by $12 \%$ and reduced mutiple births by $14 \%$ at the next lambing.

Table 2 Ewe liveweight changes in weaning date land contour experiments $(\mathrm{kg})$.

\begin{tabular}{lcccccc}
\hline & \multicolumn{2}{c}{1983184} & \multicolumn{3}{c}{$1984 / 85$} \\
\cline { 2 - 6 } & & $\begin{array}{l}\text { 14 Nov- } \\
\text { 16 Dec }\end{array}$ & $\begin{array}{c}\text { 16 Dec- } \\
\text { 12 Jan }\end{array}$ & $\begin{array}{c}\text { 15 Nov- } \\
\text { 15 Dec }\end{array}$ & $\begin{array}{c}\text { 15 Dec- } \\
\text { 07 Jan }\end{array}$ & $\begin{array}{c}\text { 07 Jan- } \\
\text { 02 Apr }\end{array}$ \\
\hline EW EC & 5.4 & 3.2 & 5.8 & 1.0 & 2.6 \\
EW & SC & 5.3 & 2.7 & 5.0 & 0.8 & 3.6 \\
LW & EC & 4.3 & 2.8 & 3.7 & 0.6 & 0.7 \\
LW S C & 4.2 & 2.1 & 4.0 & 1.0 & 0.7 \\
SED & 0.4 & 0.5 & 0.4 & 0.4 & 0.5 \\
Significance & $\bullet$ & WD & NS & "WD & NS & $\bullet$ \\
& & & $\bullet$ LC & & \\
\hline
\end{tabular}

Lambs are competitors for quality feed within mixed livestock finishing systems, and prolonged retention can jeopardise other animals performance to the detriment of per ha revenue. Once demand for quality feed exceeds supply then animals that give greater financial return per $\mathrm{kg} \mathrm{DM}$ eaten deserve priority feeding. At current prices, lamb finishing, slow growing animals and large cattle show poor $\$$ returns to consumption of limited feed.

\section{Grazing management experiment (1985/86)}

In managing periods of feed surplus (Nov-Jan) with ewes and cattle, continuous grazing has proved equal

Table 3 Steer (1983/84) and bull (1984185) liveweight change in weaning date - land contour experiments $(\mathrm{kg} \mathrm{d})$.

\begin{tabular}{lccc}
\hline & \multicolumn{2}{c}{ 1983/84 } & \multicolumn{2}{c}{1984185} \\
\cline { 2 - 5 } & 18 Nov/10 Jan & 09 Nov/17 Jan & 17 Jan/16 Apr \\
\hline EW EC & 0.83 & 0.64 & 0.13 \\
EW SC & 0.88 & 0.67 & 0 \\
LW EC & 0.64 & 0.74 & 0.07 \\
LW S C & 0.62 & 0.56 & 0.06 \\
SED & 0.03 & 0.09 & 0.05 \\
Significance & $\bullet ' W D$ & N S & 'WD \\
\hline
\end{tabular}

to quick rotation grazing in terms of pasture and animal performance (Sheath et al 1984). Unfortunately grazing method on lamb performance, or the repercussions of long rotations during late spring-early summer, were not assessed. With the exception of "steep control" (SC) farmlets in this $1985 / 86$ experiment, all animal classes had grazing access to the total farmlet area and no rank pasture (i.e.> 2.8-3.0 t DM/ha) developed. Grazing in SC farmlets was confined to $70 \%$ of farmlet area within which all steep land was included. Grazing pressure was greatest in these SC farmlets (see experiments) and greater than that required to maintain pasture control.

Tabl e 4 Lamb growth rates in the grazing management experiment $(\mathrm{g} / \mathrm{d})$.

\begin{tabular}{|c|c|c|c|c|}
\hline & 05 Nov-11 & Dec 11 & Dec-14 Jan & 14 Jan-05 \\
\hline CG & 144 & & 143 & 144 \\
\hline SC & 136 & & 138 & 138 \\
\hline QR & 164 & & 150 & 157 \\
\hline$S R$ & 148 & & 104 & 127 \\
\hline SED & 7.5 & & 9.4 & 4.9 \\
\hline Significance & . & & $\because$ & $* *$ \\
\hline
\end{tabular}

Lamb growth rates (Table 4) were highest for both the treatment (up to $14 \mathrm{Jan}$ ) and post-treatment period where lambs grazed ahead of ewes and bulls in a quick rotation (QR: 25-27 days). These lambs had the greatest opportunity for access to quality feed in this experiment. Growth rates were low in the second half of the slow rotation (SR: 43-47 days) when pasture masses were highest, but quality had declined. Continuously grazed lambs may have benefitted from a greater allocation of farmlet area, as ewe liveweight changes (Table 5) indicated that CG ewes were the best fed in the experiment. During Dee-Jan ewe performance was poorer in SR farmlets as feed quality declined; and in SC farmlets where feeding was reduced due to restricted area allocation. While not statistically significant, bull weight gains were highest during the Nov-Jan treatment period in CG farmlets where bulls "conditioned" pastures continuously grazed with lambs or ewes (Table 5)

Table 5 Ewe liveweight changes $(\mathrm{kg})$ and bull weight gains $(\mathrm{kg} /$ d) in the grazing management experiment.

\begin{tabular}{|c|c|c|c|c|c|c|}
\hline & \multicolumn{4}{|c|}{ Ewes } & \multicolumn{2}{|c|}{ Bulls } \\
\hline & $\begin{array}{l}14 \text { Nov- } \\
12 \text { Dec }\end{array}$ & $\begin{array}{c}12 \text { Dec- } \\
15 \text { Jan }\end{array}$ & $\begin{array}{l}15 \\
29\end{array}$ & $\begin{array}{l}\text { Jan- } \\
\text { Apr }\end{array}$ & $\begin{array}{l}07 \text { Nov- } \\
17 \text { Jan }\end{array}$ & $\begin{array}{l}17 \text { Jan- } \\
29 \text { Apr }\end{array}$ \\
\hline $\mathrm{CG}$ & 4.8 & 3.6 & & 2.1 & 1.12 & 0.70 \\
\hline $\mathrm{SC}$ & 2.7 & 2.1 & & 2.0 & 0.87 & 0.55 \\
\hline QR & 2.6 & 3.0 & & 1.8 & 0.94 & 0.61 \\
\hline$S R$ & 3.0 & 0.8 & & 2.8 & 0.91 & 0.61 \\
\hline SED & 0.4 & 0.6 & & 0.4 & 0.10 & 0.05 \\
\hline Significance & • & $* *$ & & .. &. & • \\
\hline
\end{tabular}


The importance of feed quality (i.e. reduced dead leaf, reduced seed head and increased legume) is well recognised when finishing lambs. Spring set-stocking and topping have both benefited pasture quality and lamb growth rates (During et al. 1980; McDonald et al. 1986). When considering the combined performance of all animal classes in this experiment, continuous or quick rotation grazing during November-January differ little, provided no rank pasture develops in the grazed area. When adopting a continuous graze strategy it is critical to include cattle grazing in order to "condition" reject pasture. Integration of sheep and cattle in hill country during late spring-summer is necessary for maximising sheep performance (McCall et al. 1986).

In order to minimise the risk of mismanagement, grazing lambs ahead of ewes and/or cattle in a quick rotation (25-30 days) seems preferable. Full access to quality feed is given, pasture quality is maintained and mobs are readily available for drafting, drenching etc. However, development of a long rotation (40-45 days) must be avoided. While bull performance did not seem to be influenced by long rotation management, both lamb and ewe weight gains were low when pastures of higher mass (2.5-3.0 t DM/ha) and lower quality developed towards the end of the rotation. To maximise lamb growth rates during Nov to Jan lambs should not graze pastures in excess of $2500 \mathrm{~kg} \mathrm{DM} / \mathrm{ha}$ mass.

\section{Early lambing experiment (1987/88, 1988189)}

Lamb growth rates of 140-160 g/d can consistently be obtained during Nov to Jan, but growth rates in excess of $80-90 \mathrm{~g} / \mathrm{d}$ are often difficult to achieve during Jan to March. This experiment (also see Webby et al. 1990) investigated the possibility that earlier lambing provides an opportunity for larger lambs, earlier drafting and premium schedules; and that improved pasture cultivars can increase early spring feed supply and maintain summer pasture quality for finishing lambs. Suffice it to say that the benefits from pasture improvement did not interact with lambing date.

Table 6 Lamb production in the lambing date experiment.

\begin{tabular}{|c|c|c|c|c|c|}
\hline & LB/EL" & $\mathrm{LW} / \mathrm{EM}^{\mathrm{a}}$ & $\begin{array}{l}\text { Weaning } \\
\text { wt (kg) }\end{array}$ & $\begin{array}{c}\text { Weaning } \\
\$ / \text { ha }\end{array}$ & $\begin{array}{l}\text { Sale } \\
\$ / \text { ha }\end{array}$ \\
\hline \multicolumn{6}{|c|}{1987188} \\
\hline Early & 1.43 & 1.12 & 23.2 & 168 & 187 \\
\hline Late & 1.58 & 1.17 & 20.6 & 152 & 176 \\
\hline SED & 0.03 & 0.03 & 0.5 & 5 & 5 \\
\hline Significance & • & NS & - $\square$ & $\star *$ & $\star$ \\
\hline \multicolumn{6}{|c|}{$1988 / 89$} \\
\hline Early & 1.40 & 0.98 & 21.3 & 67 & 136 \\
\hline Late & 1.69 & 1.29 & 19.1 & 66 & 130 \\
\hline SED & 0.05 & 0.03 & 0.3 & 3 & 6 \\
\hline Significance & . & . & $*$ & $\mathrm{~N} \mathrm{~S}$ & $\mathrm{~N} \mathrm{~S}$ \\
\hline
\end{tabular}

In 1987, lambing in early August rather than early Sept reduced multiple lamb births (LB/EL) by $15 \%$ (Table 6). This effect, plus a carry-over effect of reduced ewe weights at mating (Table 7), caused multiple births and weaning percentages to be about $30 \%$ lower for early lamb farmlets in 1988. For Romney x Coopworth ewes maximum fecundity can be expected with Sept lambing (Quinlivan \& Martin 1971). Lambing 3-4 weeks earlier increased lamb liveweight at weaning in mid Nov by $2.0-2.5 \mathrm{~kg}$ (Table 6). Weight gains of lambs from weaning until mid Jan were similar for the two lambing dates: $9.5 \mathrm{~kg}$ increase up to $13 \mathrm{Jan} 1988$ and $10.1 \mathrm{~kg}$ increase up to $18 \mathrm{Jan}$ 1989. Lamb values at weaning, and actual sale returns, were therefore a balance between increased weaning weights and reduced lamb numbers. A $\$ 10-15 /$ ha advantage with early lambing in $1987 / 88$ had disappeared in 1988/1989 because of even lower lamb numbers.

Table 7 Ewe liveweights in the lambing date experiment (kg-fasted).

\begin{tabular}{|c|c|c|c|c|c|c|c|c|}
\hline & \multicolumn{2}{|c|}{1987} & \multicolumn{4}{|c|}{1988} & \multicolumn{2}{|l|}{1989} \\
\hline & 05 May & 18 Nov & $12 \mathrm{Jan}$ & 03 & May & 18 Nov & 17 Jan & 04 May \\
\hline $\begin{array}{l}\text { Early } \\
\text { Late }\end{array}$ & 51.6 & 51.0 & 56.6 & & 7.5 & 47.8 & 51.4 & 52.3 \\
\hline $\begin{array}{l}\text { SED } \\
\text { Significance }\end{array}$ & $\begin{array}{c}51.70 .3 \\
\mathrm{NS}\end{array}$ & 355.10 .4 & $\begin{array}{ll}58.4 & 0.4 \\
\text { • } & *\end{array}$ & $*^{58.6}$ & $\begin{array}{l}0.6 \\
\text { NS }\end{array}$ & 49.11.6 & $\begin{array}{l}52.1 .7 \\
: .0\end{array}$ & $\begin{array}{c}31.9 .6 \\
.0 .\end{array}$ \\
\hline
\end{tabular}

A "see-saw" effect on ewe liveweight was measured over the 2 years (Table 7). Start weights were similar in May 1987 but by weaning, early-lambing ewes were $4.0 \mathrm{~kg}$ lighter. This difference decreased during a very favourable 1988 summer/autumn and was only $1.3 \mathrm{~kg}$ at November 1988 weaning. This small 1988 weaning difference occurred because of much higher lamb numbers in late-lamb farmlets in 1988. Ewe wool weights reflected liveweight trends, being $0.2 \mathrm{~kg} / \mathrm{ewe}$ less in early-lamb farmlets during $1987 / 88$ and similar for 1988/89. Earlier lambing placed greater nutritional stress on ewes, but its effect was moderated by reductions in lamb numbers. Greater nutrition in early lactation would be necessary to improve ewe weights

Table 8 Bull liveweights $(\mathrm{kg})$ and sale value $(\$)$ in the lambing date experiment.

1987188

05 May 13 Aug 20 Sept 09 Dec 20 Jan Value

\begin{tabular}{lrrrrrr}
\hline Early & 207 & 281 & 323 & 379 & 403 & 364 \\
Late & 208 & 285 & 360 & 408 & 429 & 388 \\
SED & & 7 & 8 & 9 & 11 & 11 \\
Significance & & NS & * * & & & ?
\end{tabular}

$1988 / 89$

\begin{tabular}{|c|c|c|c|c|c|}
\hline & 17 May & 30 Aug & $22 \mathrm{Nov}$ & 24 Jan & Value \\
\hline Early & 250 & 320 & 390 & 459 & 600 \\
\hline Late & 240 & 330 & 412 & 473 & 638 \\
\hline SED & & 6 & 6 & 7 & 14 \\
\hline Significance & & NS & ** & . & \\
\hline
\end{tabular}


and eliminate some of the reduction in ewe fecundity (McCall et al. 1986a). New pasture cultivars did not improve early lactation nutrition in this experiment (Webby et al. 1990), but reduced stock numbers or the application of nitrogen are alternative options that would require production and economic analysis. At weaning, ewe weights will be much more responsive than lamb weights to alternative spring feeding managements.

During spring, bull weight gains were $20-30 \mathrm{~kg}$ lower in early lambing farmlets (Table 8) and this weight disadvantage continued to sale. At approximately 1 bull/ha, the $\$ \mathbf{2 5 - 3 5}$ reduction in bull value at sale negated any lamb $\$$ advantage accruing from early lambing. Certainly early-lambing strategies are in direct competition for feed with cattle finishing policies. When considering lambing date options (e.g. Andrewes \& Taylor; 1986, Lowe et al. 1988) the impact on production on profitability of other stock classes must be considered.

\section{CONCLUSIONS}

The implications of these results for finishing lambs in mixed livestock svstems in hill country are:

- High lamb growth on steep land during NovemberJanuary is feasible provided pasture mass of grazed paddocks is within the range of 1.4-2.5 $\mathrm{t} \mathrm{DM} / \mathrm{ha}$.

- For performance and management precision during Nov-Jan it is preferable to graze lambs ahead of ewes and cattle in a quick rotation (25-30 days). Long rotations $(\simeq 45$ days) must be avoided.

- Changes in weaning date have much less impact on animal production than differences in lamb disposal date. Later selling of lambs can jeopardise the performance of other stock classes.

- Early lambing provides an opportunity for heavier lambs being available for earlier disposal. However, reduced lamb numbers, lower spring weight gains of cattle and poorer ewe performance mean it is not a financially feasible option in mixed livestock farming in hill country given current product values.

Under current price relativities between lamb and beef, lamb production can be considered as a "catch crop" of mixed livestock farming in hill country. It should be done well during the period of strong pasture growth (Sept to Jan), but should not be extended outside this time frame if it is going to jeopardise the performance of other stock, most notably growing cattle.

\section{REFERENCES}

Andrewes, W.G.K.; Taylor, A.O. 1986. Autumn and winter lambing strategies in Northland. Proceedings of the NZ Grassland Association 47: 81-87.

During, C.P.; Dyson, C.B.; Webby, R.W. 1980. Relationship of pasture parameters to liveweight gain of hoggets on North Island hill country. Proceedings of the NZ Society of Animal Production 40: 90-105.

Knight, T.W. 1983. Ram induced stimulation of ovarian and oestrous activity in anoestrous ewes - a review. Proceedings of the NZ Society of Animal Production 43: 7-11.

Lowe, K.I.; Carter, M.L.; McCutcheon, S.N. 1988. Developing systems for out-of-season lambing at Limestone Downs. Proceedings of the NZ Society of Animal Production 48: 95-98.

McCall, D.G.; Smeaton, D.C.; Gibbison, M.L. 1986. The influence of sheen to cattle ratios on liveweight gain on pastures grazed to different levels in late spring-summer. Proceedings of the NZ Society of Animal Production 46: 121-124.

McCall, D.G.; Smeaton, D.C.; Wadam, T.K 1986a Lambing date. ewe liveweieht and pasture mass effects on ewe and lamb performance during lactation. Proceedings of the NZ Society of Animal Production 46: $129-132$

McDonald, R.C.; van Leeuwen, M.J.; Harris, C.G. 1986. Effect of topping pastures 2. Lamb growth during summer. NZ Journal of Experimental Agriculture 14: 291-296.

Quinlivan, T.D.; Martin, C.A. 1971. Oestrous activity and lamb production in the New Zealand Romney ewe. Australian Joumal of Agricultural Research 22: 497-511.

Sheath, G.W.; Webby, R.W.; Pengelly, W.J. 1984. Management of late spring-early summer pasture surpluses in hill country. Proceedings of the NZ Grassland Association 45: 199-206.

Sheath, G.W.; Webby, R.W.; Boom, R.C. 1987. Facial eczema in hill country potential toxicity and effects on ewe performance. Proceedings of the NZ Society of Animal Production 47: 45-48.

Webby, R.W.; Sheath, G.W.; Boom, C.J. 1990. The performance of new pasture cultivars in hill country finishing systems. Proceedings of the NZ Grassland Association (in press). 